\title{
Buddhist and Shinto influences on Yosano Akiko's "The Tangled Hair" poetry collection
}

\author{
H. Vozniuk \\ Taras Shevchenko National University of Kyiv \\ Corresponding author. E-mail: hanna.vozniuk@gmail.com
}

Paper received 09.10.20; Accepted for publication 26.10.20.

\begin{abstract}
https://doi.org/10.31174/SEND-Ph2020-240VIII71-14
\end{abstract}
\begin{abstract}
The article deals with the influences of Buddhist and Shinto religion on the debut collection of tanka poetry called "Midaregami" ("The Tangled Hair", 1901) by famous Japanese poetess Yosano Akiko. We have analyzed the primary religious terms that were used in the collection. We have also distinguished the main reasons for the religious influences and the origins of the literary images. Our research shows part of the complicated process of the renovation of the traditional tanka genre. During it, the poetess managed not only to make tanka poetry more up-to-date but also saved its unique features and topics.
\end{abstract}

Keywords: tanka verses, Buddhism, Shinto, religion, poetry.

Introduction. The beginning of the modern period in Japanese literature after the Meiji Restoration in 1868 was connected to the denial of tradition, searching for the new style and manner inspired by the constant flow of European literary works' translation. But some writers managed to balance wisely between the acceptance of the new and preservation of the traditional. The poetess Yosano Akiko (1878 - 1942) was among them. She is considered to be one of the most outstanding authors of the beginning of the $20^{\text {th }}$ century. Though most of her poems were written in the traditional Japanese tanka genre (5-7-5-7-7), they differed from traditional tanka verses. Yosano Akiko's debut collection of poetry called "Midaregami" ("The Tangled Hair", 1901) was remarkably frank for the conservative Japanese society, showing very private women's feelings and desires. She also introduces the eroticism to her poetry, which was also considered inappropriate for the female literary work. But her most outstanding achievement, in our opinion, was the fact that she managed to revive the tanka genre making it more individual and up-to-date.

In our research, we are particularly interested in Buddhism and Shinto's influence on Yosano Akiko's "The Tangled Hair" collection. It is easy to notice that a large layer of vocabulary in the collection belongs to it. Buddhism and Shinto are the two most widespread religions in Japan. It is not surprising, therefore, that their influence on Yosano Akiko's poetry took place. However, in addition to the general prevalence of these religions, their motives in the poetess's work had other prerequisites.

Review of publications. Among the Japanese studies of the creative work of Yosano Akiko are the thorough works of Satake Kazuhiko - "The Study of "The Tangled Hair" Anthology and a Full Commentary on it" ("Zenshyaku" Midaregami "Kenkyu", 1957) and Itsumi Kumi "The Critical Biography of Tekkan and Akiko" ("Hyoden Yosano Hiroshi Akiko", 2007). A critical study related to the immediate topic is a scientific article by Japanese researcher Akashi Toshio entitled "The Tangled Hair and Religious Expressions" ("Midaregami to shyukyoteki hyogen"). It is also worth noting the work of American researcher J. Baichman "Embracing the Firebird" ("Capturing a firebird", 2002).

This article aims to analyze the collection of poetry "The Tangled Hair" Yosano Akiko's and to distinguish the primary religious terms used in the collection. We are eager to find out the main reasons for the religious influences on Akiko's poetry and the origins of the collection's literary images.

Methods and materials. In our research we used several general scientific methods, such as analysis and synthesis, induction and deduction. To achieve the study's aim, we also used such specific methods as descriptive, biographical, cultural-historical, and mytho-poetic methods. The research material includes the collection of poetry "The Tangled Hair" by Yosano Akiko in the Japanese language.

Results and discussion. In "An Essay on New Japanese Poetry," the poet Yosano Tekkan (1873-1935) wrote about Akiko: "The unique feature of this poetess is that she takes many images from Japanese songs: a young traveler, a young monk, a young artist." Of course, the appearance of Buddhist motifs in the entire Japanese picture of the poet's world is not surprising, but, interestingly, the image of a young Buddhist monk managed to take no less bright place than a traveler or artist. [1]

A young Buddhist monk's image appears in 7 verses (№ $42,99,120,158,159,221,229)$ of the collection "The Tangled Hair". Japanese researcher Akashi Toshio believes that this image became not only one of the brightest images in the collection but also took center stage in the magazine "The Morning Star" ("Myojo") in 1901. [1] For this image, the poet used two words: 僧 ("so" - "monk") and 聖 (" $h i$ jiri" - "a saint, a spiritual person"). The following verses can serve as an example of their use:

旅のやど水に端居の僧の君をいみじと泣きぬ夏の

$$
\text { 夜の月 }
$$

(from "The Tangled Hair", № 42)

An inn for travelers -

There you sat by the water's edge

o priest, so pure and

so forbidding that I wept

beneath the summer moon

あまきにがき味うたがひぬ我を見てわかきひじり

の流しにし涙

(from "The Tangled Hair", № 221)

Sweet of bitter

how did the tears taste

looking at me

a young priest 


\section{falls into weeping}

[6, p. 137]

According to most researchers, a young monk's image came into Akiko's poetry from her personal life. In fact, it is the image of a young Yosano Tekkan who has just received or is receiving a spiritual education. Tekkan never served at the temple, but had a spiritual rank, as insisted by the poet's father, a Buddhist priest. Tekkan could not get a secondary education due to his spiritual training, but he studied Japanese and Chinese poetry under the guidance of his father. The time of the appearance of the image in Akiko's poetry coincides with the beginning of a closer relationship between the poets, so it is not surprising that she was inspired by events from the early years of Tekkan's life. [1] It is worth noting that the images of "poet" (詩人 - "shijin") and "traveler" (旅人 - "tabibito") appeared in the same year as the monk's one (1901). So, according to Akashi Toshio, we can say that they were also formed from the image of Yosano Tekkan. [1]

In "The Tangled Hair" collection along with the image of a monk appeared such Buddhist realities and terms as "sutra" (経 - "kyo", verses №7, 20, 103, 150, 159, 229, 393), including including the Lotus Sutra (法 華 経 - "hockkekyo", verse №121) and the "funeral sutra" (枕 経 - "makuragyo"; the sutra recited over the deceased; verse № 123), the "white lotus" (白蓮 - "shirahasu", verses № 35, 99, 160, 161, 176), "red lotus" (紅蓮 - "guren", verse № 99), "sandalwood smoke" (白檀のけむり - "byakudan-no kemuri", verse № 122 ), "nun" (尼 - "ama"), "bothisattva" (菩 薩 - "bosatsu"; enlightened being; verse № 20), "bodhisattva Maitreya" (弥勒 - "miroku"; future Buddha who will appear at the end world; verse № 216), "Buddha" (仏 "hotoke"; verse № 150), "temple" (堂 / 寺 - "to / tera", verses № 112, 231, 268, 285), etc.

Interestingly, in the poems of "The Tangled Hair" collection, there are names of many basic elements of the Buddhist temple complex: "complex of temple buildings" (伽藍 - "garan", verse № 347), "pagoda" (層 塔 - "sotafu", verse № 171), "temple kitchen" (庫裏 - "kuri"), "temple bell" (堂の鐘 / 寺の 鐘 - "to-no kane / tera-no kane", verses № 7, 142), "main temple" (奥 の 院 - "oku-no in"). For example, the following verse mentions both the element of the temple complex and the Buddhist term "bodhisattva":

$$
\begin{gathered}
\text { 経はにがし春のゆふべを奥の院の二十五菩薩歌う } \\
\text { けたまへ } \\
\text { (from "The Tangled Hair", № 20) } \\
\text { Sutras are bitter - } \\
\text { This lovely night of spring } \\
\text { accept my poems, } \\
\text { you twenty-five }
\end{gathered}
$$

Bodhisattvas of the Inner Cloister

$[2$, p. 211]
In addition, the poetess mentions in her lyrics several important Buddhist temples in Japan: "Buddha Vairochana" (盧遮那仏 - "rushyana butsu", a statue of the Great Buddha in the Todai-ji Temple in Nara; verse № 36), "Kiyomizu Temple" (清水 - "kiyomizu", poems № 18, 156, 301), "Five Monasteries" (五 山 - "godzan"; system of "five mountains" - the five most important Zen Buddhist monasteries in Kyoto; poem № 281), "Mount Kurama" (鞍 馬 - "kurama", a sacred mountain north of Kyoto; verse № 173). An example is the following verse:

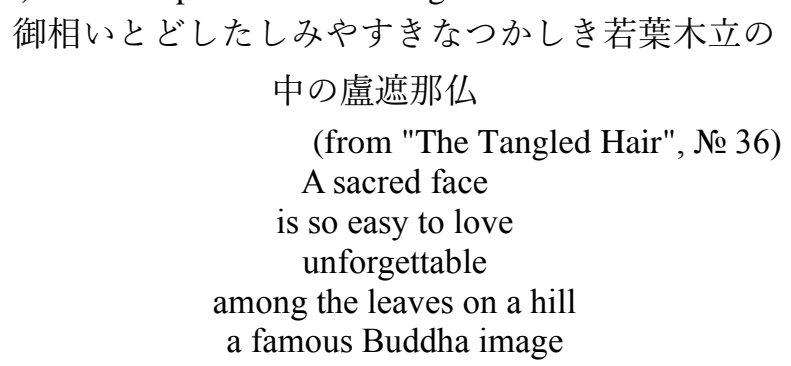

The number of Buddhist realities and terms in Yosano Akiko's debut "The Tangled Hair" collection outnumbers any Christian and Ancient Greek and Roman inclusions. In addition to the poet's interest in her beloved's young image, there are other reasons for the poet's great attention to this topic. First of all, this is her little homeland. Akiko grew up in Sakai's small provincial town, $15 \mathrm{~km}$ from Osaka and close to Nara and Kyoto, the entire Kansai region's actual cultural and historical centers. The temples and shrines of the area have been part of the picture of the poet's world since childhood.

Along with that, at the very place of Sakai, as it leads the history from Muromachi's era (1336-1573), there were even more Buddhist temples. Akiko also mentioned "her aunt the nun" (verse № 268) and "a priest-friend" (verse № 231) in her poems. Japanese researcher Akash Toshiyo says that Akiko's friends from the literary society, Kono Tetsunan (1874-1940) and Kusunoki Masue, were born and lived at the temples during a long time. We can conclude that the future poetess had an opportunity to get to know the Buddhist temple's mode of life pretty close.

It is worth noting that Akiko did not like the town Sakai because she considered it very provincial, but there is no denying that it greatly influenced the poetess's worldview. And the picture of her world looked like this:

$$
\begin{gathered}
\text { 四十八寺そのひと寺の鐘なりぬ今し江の北雨雲ひ } \\
\text { くき } \\
\text { (from "The Tangled Hair", №142) } \\
48 \text { temples } \\
\text { in one of them } \\
\text { a bell tolls } \\
\text { just now north of the bay } \\
\text { a rain cloud hangs low }
\end{gathered}
$$

As for another Japanese religion, Shinto, we can confidently say that it is rooted in the very mentality and worldview of the Japanese people. Shinto is a religion that glorifies life. Unlike Buddhism and Christianity, it does not promise any afterlife or salvation. This religion explains the origin of the world and the Japanese people, as well as 
endows all living and non-living around the soul. Shinto is based on animism, ancestral worship and the elements of shamanism. [3, p. 101]

The motives of Shinto in Yosano Akiko's poetry may be seen in the image of "the country of spring". It is the country of love and eternal youth, which the poetess repeatedly mentions in her debut collections "The Tangled Hair". Her lyrical heroine and her lover are set there. In the following verse, according to the American researcher J. Beichman, this image comes its apogee:

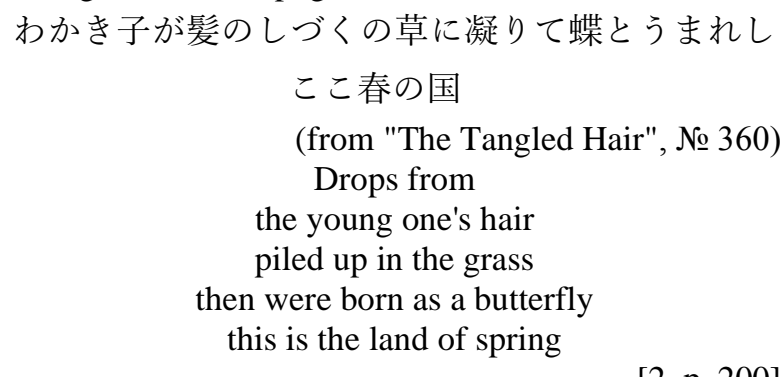

We see the process of transformation of an inanimate object, drops, into living beings - butterflies. This process is the very essence of the Shinto religion: spiritualization. Moreover, the poetess took the verb "凝る" ("koru" "gather" in this case) from the myth of the creation of Japan by the god Izanagi and the goddess Izanami, described in the "Records of Ancient Matters" ("Kojiki", 712). The word is used in the myth when the pieces of land that have fallen from the Divine spear have gathered and formed the first Japanese island. That wors stresses Akiko's original idea and shows the connection with the national religion. The poem is the poetess's version of the divine creation myth, and the lyrical heroine is a deity. [2, p. 200]

Another evidence of Shinto influence on the poetess's worldview is the fact that Akiko's lyrical heroine addresses to her lover as "the god of the night", "the god of spring", "the god of rooms", "the evening god", "the god of autumn" and even "the god of the Kamo River," thus following the Shinto belief in the existence of a "kami deity" in the unliving things:

御袖くくりかへりますかの薄闇の欄干夏の加茂川の神

(from "The Tangled Hair", № 48)

In summer twilight

tucking up his sleeves shall we go

said the god of Kamo River

at the railing of the bridge

[6, p. 50]

なほ許せ御国遠くば夜の御神紅盃船に送りまみらせむ

(from "The Tangled Hair", № 49)

\author{
Pardon me and \\ if your sacred land is far \\ god of night \\ I will offer as send-off \\ a boat as a red wine cup
}

$[6$, p. 51]

Finally, it is worth mentioning Shinto's feature as the lack of moral precautions related to carnal desires, the presence of numerous erotic scenes, even the central sacred text of Shinto - "Kojiki". This frank eroticism is also typical for the first anthology of Japanese poetry "Manyoshu" ("Collection of Ten Thousand Leaves", $8^{\text {th }}$ century), a collection that Akiko first read at the age of 15 and which she liked very much. Apparently, it was this primal Shinto eroticism, which was later imposed by numerous Buddhist and Confucian restrictions and dogmas, that Yosano Akiko was able to liberate in her poetry:

$$
\begin{gathered}
\text { 泣かで急げやは手にはばき解くえにしえにし持つ } \\
\text { 子の夕を待たむ } \\
\text { (from "The Tangled Hair", № 127) } \\
\text { Hurry up and don't cry } \\
\text { don't you think the one who is } \\
\text { untying your leggings } \\
\text { is so bound to you } \\
\text { she will wait until evening }
\end{gathered}
$$

Conclusions. Summing up, we should say that there are numerous Buddhist and Shinto inclusions in Yosano Akiko's "The Tangled Hair" poetic collection. In particular, it is the appearance of the iconic image of a "young Buddhist monk" who is in an internal struggle between the feelings and moral tenets of his religion. It has a complex structure and was formed from the image of the poet Yosano Tekkan and the elements of Yosano Akiko's childhood. That includes Akiko's close acquaintance with Buddhist life in her hometown of Sakai, which allowed her to incorporate numerous Buddhist realities and terms into her poetry organically. We have distinguished a large number of terms that belong to Buddhism in Yosano Akiko's "The Tangled Hair" collection of poems. That includes the main elements of the Buddhist monastery complex and several important Buddhist temples.

As for Shinto motives, we can see them in the examples of the poetess's use of animistic elements, the spiritualization of the inanimate and the presence of Shinto eroticism, freedom of love, opposition to the Confucian conventions.

We consider the research of religious influence on Yosano Akiko's literary heritage to be significant because it shows how the tanka verses have managed to become upto-date poetry saving its unique traditional features.

\section{REFERENCES}

1. 明石, 利代. (1984)『みだれ髪』と宗教的表現.（Akashi

3. Bondar O.I., Bondarenko I.P. (2012) Linhvokrainoznavstvo yaponii: navchalnyi pidruchnyk [Japanese Language and Culture Studies] Kyiv: Dmytro Burago's Publishing House.

Toshio. "Midaregami" to shyukyoteki hyogen.) [Akashi Toshio. "The Tangled Hair" and religious phrases.] 女子大文 学. 国文篇. DOI: 10.24729/00011106

2. Beichman J. (2002). Embracing the Firebird: Yosano Akiko and the Birth of Female Voice in Modern Japanese Poetry. Honolulu, HI: University of Hawai'i Press.

4. 逸見，久美. (2007)。『新みだれ髪全釈 晶子第一歌集』 (Itsumi Kumi. Shin "Midaregami" Dzenshiaku) [Itsumi Kumi. The new full commentary on the anthology "The Tangled Hair"] Tokio: Yagi Shoten.

5. Keene D. (1999). Dawn to the West. New York, NY: Columbia University Press.

6. Reichhold J., Kobayashi M. (2014). A Girl with Tangled Hair. Gualala, CA: AHA Books. 